\title{
PENGARUH PERSEPSI HARGA, PROMOSI PENJUALAN, DAN CITRA MEREK TERHADAP KEPUASAN UNTUK MENINGKATKAN LOYALITAS PELANGGAN
}

\author{
Ida Ayu Komang Sri Suastini ${ }^{1}$ \\ Kastawan Mandala ${ }^{2}$ \\ ${ }^{1,2}$ Fakultas Ekonomi dan Bisnis Universitas Udayana, Bali, Indonesia \\ e-mail: dayuomang29@gmail.com
}

\begin{abstract}
ABSTRAK
Penelitian ini ingin menjelaskan pengaruh persepsi harga, promosi penjualan, dan citra merek terhadap kepuasan untuk meningkatkan loyalitas pelanggan.Penelitian ini dilakukan di Kota Denpasar yang melibatkan 105 responden dengan menggunakan purposive sampling sebagai metode dalam pengambilan sampel. Pengumpulan data dilakukan dengan menyebarkan kuesioner yang berisikan pernyataan berkaitan dengan variabel persepsi harga, promosi penjualan, citra merek, kepuasan pelanggan dan loyalitas pelanggan. Selanjutnya, data dari hasil pengumpulan kuesioner tersebut diolah dengan menggunakan uji validitas, dan uji reliabilitas untuk mengetahui kelayakan dan konsistensi indikator dalam kuesioner. Teknik analisis yang digunakan dalam penelitian ini adalah analisis jalur (path analysis) dan Teori Solimun.Hasil dari penelitian ini ditemukan bahwa persepsi harga, promosi penjualan, dan citra merek berpengaruh positif dan signifikan terhadap kepuasan pelanggan. Kepuasan pelanggan memiliki pengaruh positif dan signifikan terhadap loyalitas pelanggan.
\end{abstract}

Kata kunci: persepsi harga, promosi penjualan, citra merek,kepuasan pelanggan, loyalitas pelanggan.

\begin{abstract}
This research would like to explain the influence of price perception, sales promotion, and brand image to satisfaction to increase customer loyalty. This study was conducted in Denpasar City involving 105 respondents by using purposive sampling as a method in sampling. Data collection is done by distributing questionnaires containing statements relating to the variables of price perception, sales promotion, brand image, customer satisfaction and customer loyalty. Furthermore, data from the results of collecting the questionnaire is processed by using the validity test, and reliability test to determine the feasibility and consistency of indicators in the questionnaire. The analysis technique used in this research is path analysis and Solimun theory. The results of this study found that the perception of prices, sales promotion, and brand image have a positive and significant impact on customer satisfaction. Customer satisfaction has a positive and significant influence on customer loyalty.
\end{abstract}

Keywords: price perception, sales promotion, brand image, customer satisfaction, customer loyalty. 


\section{PENDAHULUAN}

Perkembangan ekonomi, teknologi dan budaya di era globalisasi seperti saat ini menimbulkan kebutuhan manusia semakin berkembang, tidak hanya terbatas pada kebutuhan pokok, tetapi juga pada kebutuhan pribadi. Pemenuhan kebutuhan pribadi ini menjadi kebutuhan penting bagi beberapa kalangan tertentu sehingga menempati tempat yang sama dengan kebutuhan pokok dalam hal pemenuhannya. Kebutuhan pribadi yang sering dituntut pemenuhannya oleh kaum wanita adalah menjaga penampilan melalui perawatan kesehatan dan kecantikan (Purbarani, 2013). Penampilan yang cenderung tidak menarik akan merasa tersisih dari lingkungan pergaulannya. Para wanita rela mengeluarkan biaya besar untuk melakukan perawatan kecantkan. Namun, bukan hanya kaum wanita saja yang sangat memperhatikan kesehatan kulit terutama kulit wajah, diera modern saat ini tidak sedikit kaum pria yang melakukan perawatan wajah untuk menjaga kesehatan kulitnya.

Kecantikan dipandang sebagai kebutuhan pokok yang pada saat tertentu harus dipenuhi, bahkan kaum pria sudah banyak yang menggunakan jasa klinik kecantikan (Afifah, 2014). Perilaku konsumen tersebut menyebabkan kebutuhan akan kecantikan semakin meluas dikalangan masyarakat. Melihat kenyataan tersebut, maka banyak bermunculan jasa klinik kecantikan yang menawarkan berbagai macam perawatan wajah dan rambut. Manfaat dari adanya klinik kecantikan sangat memudahkan bagi konsumen untuk memenuhi kebutuhan dalam merawat dan menjaga kesehatan kulit. Klinik kecantikan juga menawarkan produk yang biasanya berupa obat-obatan dan dikemas dalam berbagai macam 
kosmetik yang digunakan sehari-hari sebagai kelanjutan dari perawatan agar konsumen mendapatkan hasil sesuai dengan yang diingkinkan.

Gaya hidup masyarakat yang semakin peduli akan penampilan terutama dalam merawat kesehatan kulit menjadi peluang usaha bagi perusahaan bidang kecantikan dalam mengembangkan usahanya di Indonesia. Setidaknya lebih dari 5 jenis klinik kecantikan mulai membuka cabang baru yang tersebar diseluruh kotakota besar di Indonesia. Strategi membuka cabang di berbagai kota tersebut dilakukan demi memenangkan pesaingan dan memantapkan pilihan pelanggan akan sebuah klinik kecantikan. Data Tabel 1 menunjukkan mengenai popularitas klinik kecantikan di Indonesia pada tahun 2017.

Tabel 1.

\section{Top Brand Award Kategori Retail Tahun 2017}

\begin{tabular}{clc}
\hline No & Merek & TBI $(\%)$ \\
\hline 1. & Natasha Skin Care & 40.1 \\
2. & Erha Clinic & 17.4 \\
3. & London Beauty Center & 6.4 \\
4. & Miracle Skin Care & 2.9 \\
5. & Larissa Aesthetic Center & 2.6 \\
6. & Klinik Dr. Eva Mulia & 2.4 \\
7. & Estetika & 1.5 \\
\hline
\end{tabular}

Sumber: Topbrand-award.com, 2017.

Terdapat 7 perusahaan klinik kecantikan yang bersaing memasarkan produk dan jasa perawatan kulit di Indonesia. Natasha Skin Care menduduki peringkat 1 dalam Top Brand Award Kategori Rentail sebesar 40,1\%. Klinik kecantikan Larisaa Aesthetic Center memiliki Top Brand Index (TBI) sebesar 2,6\% di Indonesia, angka ini menggambarkan Larissa Aesthetic Center cukup familiar dibenak konsumen. Saat ini mulai banyak muncul klinik kecantikan yang menawarkan produk dan jasa dengan harga bervariasi yang terdapat di Kota 
Denpasar. Berikut ini data hasil observasi beberapa klinik kecantikan yang ada di Kota Denpasar.

Tabel 2.

Observasi harga facial treatment klinik kecantikan di Kota Denpasar

\begin{tabular}{llc}
\hline No & \multicolumn{1}{c}{ Klinik Kecantikan } & Kisaran Harga $(\mathbf{R p})$ \\
\hline 1. & Natasha Skin Care & $200.000-1.200 .000$ \\
2. & London Beauty Center & $61.000-500.000$ \\
3. & Larissa Aesthetic Center & $80.000-350.000$ \\
4. & D\&I Skin Center & $130.000-600.000$ \\
5. & MS GLOW Aesthetic Clinic & $150.000-350.000$ \\
\hline
\end{tabular}

Sumber: Observasi harga di Kota Denpasar, 2017.

Hasil observasi harga perawatan pada klinik kecantikan di Kota Denpasar pada bulan Oktober 2017 menyimpulkan bahwa Larissa Aesthetic Center dan MS GLOW Aesthetic Clinic merupakan klinik kecantikan yang menyasar segmen konsumen kelas menengah. Harga yang ditawarkan oleh Larissa Aesthetic Center dapat dikategorikan sebagai harga yang cukup terjangkau apabila dibandingkan dengan harga yang ditawarkan oleh para pesaingnya. Harga yang cukup terjangkau menjadi salah satu daya tarik bagi konsumen untuk memilih Larissa Aesthetic Center dibandingkan dengan klinik kecantikan lainnya. Klinik kecantikan Natasha Skin Care, D\&I Skin Center, dan LBC menyasar segmen konsumen kelas atas dengan harga perawatan yang cukup mahal.

Larissa Aesthetic Center merupakan salah satu klinik kecantikan yang berusaha memenuhi kebutuhan konsumen akan perawatan kecantikan. Berawal pada tanggal 11 Juni 1984 oleh R. Ngt. Poetji Lirnawati mendirikan Larissa Beauty Salon yang berangkat dari sebuah keinginan memberikan pelayanan dibidang perawatan kulit dan rambut yang sehat tanpa efek samping. Larissa Aesthetic Center mengembangkan konsep "back to nature" dimana sistem perawatan wajah, perawatan rambut hingga perawatan tubuh dengan memakai 
bahan alami (www.larissa.co.id). Tidak hanya kaum wanita saja namun kaum pria dapat melakukan perawatan di klinik kecantikan Larissa Aesthetic Center.

Larissa Aesthetic Center yang beralamat di Jalan Pulau Misol, Dauh Puri, Denpasar Barat. Berada ditengah-tengah Kota Denpasar menjadikan semakin tinggi pesaing bagi bisnis serupa dalam mengembangkan usahanya. Tingginya tingkat persaingan maka penting bagi perusahaan untuk menjaga konsumen, karena hal tersebut mampu meningkatkan pendapatan (profit) bagi perusahaan. Oleh sebab itu, diperlukan strategi pemasaran yang tepat untuk dapat mempertahankan pelanggan agar mampu bertahan di bisnis ini.

Loyalitas pelanggan akan muncul jika konsumen merasa puas akan pelayanan dan produk yang dikonsumsinya (Hermawan, 2011). Selain menyasar segmen pasar yang tepat dan mempertahankan konsep dari perusahaan, penting bagi perusahaan untuk menjaga loyalitas konsumen. Memberikan jasa dan produk yang berkualitas sehingga mampu membangun citra merek di mata konsumen menjadi salah satu cara perusahaan untuk memciptakan loyalitas konsumen (Chaeriah, 2016). Hal ini diharapkan akan memberi dampak positif bagi klinik kecantikan Larissa Aesthetic Center diantaranya minat beli kembali konsumen dan merekomendasikan produk kepada teman atau keluarga. Pelanggan yang loyal juga mempunyai kecenderungan yang lebih rendah untuk melakukan perpindahan merek.

Kepuasan merupakan perasaan senang atau kecewa seseorang yang timbul karena membandingkan kinerja yang dipersepsikan produk atau hasil terhadap ekspektasi merek (Kotler dan Keller, 2009:139). Kunci utama dalam menciptakan 
loyalitas pelanggan adalah dengan memberikan kepuasan bagi pelanggan (Espejel et al., 2008). Loyalitas pelanggan akan timbul saat konsumen merasa puas akan produk atau jasa yang dikonsumsi. Penelitian Selmi (2007), menemukan bahwa kepuasan konsumen berpengaruh positif dan signifikan terhadap loyalitas pelanggan. Penelitian Briliana (2013),menemukan bahwa kepuasan konsumen berpengaruh positif dan signifikan terhadap loyalitas pelanggan. Meningkatkan kepuasan pelanggan menjadi tanggung jawab Larissa Aesthetic Center demi menjaga menjaga loyalitas pelanggan, sehingga pelanggan puas dengan kinerja produk atau jasa secara umum.

Persepsi konsumen terhadap harga yang ditawarkan dapat mempengaruhi kepuasan pelanggan. Saat pelanggan merasa harga yang dibayarkan sesuai dengan kualitas yang didapatkan, maka hal ini akan menimbulkan kepuasan pelanggan (Montung dkk., 2015). Persepsi harga tidak hanya berdampak pada kepuasan pelanggan, tetapi berdampak pula pada loyalitas pelanggan. Kesesuaian harga yang dibayarkan dengan kualitas yang diterima dapat meningkatkan loyalitas pelanggan terhadap suatu produk (Sinaga dan Novianti, 2016).

Persepsi harga berkaitan dengan penilaian terhadap harga yang dipengaruhi oleh persepsi konsumen, sehingga pada akhirnya suatu produk dapat dikataan memiliki harga yang mahal ataupun murah (Peter dan Olson, 2000:228). Penelitian Darmawan dan Ekawati (2017), menemukan bahwa harga berpengaruh positif dan signifikan terhadap loyalitas pelanggan. Penelitian oleh Sulastri (2017), menemukan bahwa harga berpengaruh positif dan signifikan terhadap loyalitas pelanggan. Menawarkan harga bersaing dengan tetap menghadirkan 
kualitas produk dan jasa dari klinik kecantikan Larissa Aesthetic Center yang baik akan menciptakan persepsi harga yang positif dibenak konsumen. Saat konsumen merasa biaya yang dikorbankan sebanding dengan kualitas produk dan jasa klinik kecantikan yang didapat, maka hal ini tidak hanya akan menciptakan kepuasan pelanggan namun juga menciptakan loyalitas pelanggan.

Promosi merupakan faktor penting dalam mewujudkan tujuan penjualan suatu perusahaan. Selain memberikan harga yang sesuai diperlukan promosi penjualan yang tepat agar dapat menarik minat beli konsumen. Penelitian Sengkey dan Tumbuan (2014), menemukan bahwa promosi berpengaruh positif dan signifikan terhadap kepuasan pelanggan. Penelitian Khan et al. (2012), menemukan bahwa promosi penjualan berpengaruh postif dan signifikan terhadap kepuasan pelanggan. Perusahaan perlu mengadakan promosi yang terarah, karena diharapkan dapat memberikan pengaruh positif terhadap meningkatnya penjualan (Sugiyono, 2016). Berbagai jenis dan cara promosi banyak dilakukan oleh perusahaan untuk meningkatkan minat dan memperoleh perhatian konsumen.

Perusahan melakukan beberapa cara dalam mempromosikan produknya. Promosi penjualan yang dilakukan Larissa Aesthetic Center antara lain dengan iklan di beberapa media, memberikan diskon khusus untuk member atau pada periode tertentu, juga memberikan undian berhadiah. Hal tersebut dilakukan untuk menarik minat konsumen untuk melakukan perawatan kulit di Larissa Aesthetic Center.

Selain melakukan promosi penjualan yang sesuai, perusahaan perlu membangun citra merek yang positif kepada konsumen untuk menciptakan 
kepuasan pelangga. Citra merek juga dapat diartikan sebagai deskripsi tentang asosiasi dan keyakinan konsumen terhadap merek tertentu (Tjiptono, 2005:49). Citra merek yanga baik akan mendorong para calon pembeli untuk membeli produk tersebut dari pada membeli produk yang sama dari merek lain (Seno dan Bryan, 2017). Fungsi citra merek adalah untuk menjawab pertanyaan tentang bagaimana konsumen memilih diantara merek alternatif setelah melakukan pengambilan informasi (Adil, 2012). Penelitian Susanti dan Wardana (2015), menemukan bahwa citra merek berpengaruh positif dan signifikan terhadap kepuasan pelanggan produk kosmetik hijau merek The Body Shop. Penelitian oleh Kurniawati dkk. (2014), menemukan bahwa citra merek berpengaruh positif dan signifikan terhadap kepuasan pelanggan.

Penelitian mengenai persepsi harga, promosi penjualan, dan citra merek klinik kecantikan pernah dilakukan oleh Purbarani (2013). Penelitian oleh Yoganthara (2013), menemukan bahwa persepsi harga berpengaruh positif signifikan terhadap kepuasan. Penelitian oleh Saradissa (2015), menemukan bahwa promosi penjualan berpengaruh positif terhadap kepuasan pelanggan. Penelitian Saputra (2013), menemukan bahwa citra merek yang baik akan meningkatkan kepuasan pelanggan.

Hasil berbeda ditemukan dalam penelitian Amryyanti dan Cahya (2013), dalam penelitian tersebut persepsi harga tidak memberikan pengaruh pada loyalitas pelanggan. Penelitian Sinaga dan Novianti (2016) menemukan bahwa citra merek tidak berpengaruh signifikan terhadap loyalitas pelanggan. Sejumlah penelitian yang disajikan menunjukkan adanya hasil yang tidak konsisten dalam 
hubungan antara persepsi harga dan citra merek dengan loyalitas pelanggan. Hal ini diduga karena terdapat satu variabel yaitu kepuasan yang berperan penting dalam menentukan loyalitas pelanggan. Penelitian mengenai hubungan kepuasan terhadap loyalitas pelanggan pernah diteliti oleh Afifah (2014), menemukan bahwa kepuasan berpengaruh positif terhadap loyalitas pada pelanggan Larissa Aesthetic Center Semarang.

Teori yang digunakan dalam penelitian ini adalah teori pemasaran. Menurut teori tersebut kegiatan pemasaran mempengaruhi konsumen untuk bersedia membeli barang dan jasa perusahaan di saat mereka membutuhkan. Hal ini sangat penting bagi perusahaan untuk memahami "mengapa" dan "bagaimana" tingkah laku konsumen tersebut sehingga perusahaan dapat mengembangkan (produk), menentukan harga, mempromosikan dan mendistribusikan produknya secara lebih baik. Selain teori pemasaran, teori perilaku konsumen diperlukan dalam perusahaan untuk mengetahui pembeli individual berusaha menggunakan barang - barang yang akan memberikan kegunaan (kepuasan) paling banyak, sesuai dengan selera dan harga - harga yang relatif. Teori perilaku konsumen disempurnakan oleh ahli-ahli eknomi neoklasik yaitu teori kepuasan marginal (marginal utility), menurut teori ini konsumen akan berusaha mendapatkan kepuasan maksimal, dan konsumen akan meneruskan pembeliannya terhadap suatu produk untuk jangka waktu yang lama, bila konsumen telah mendapatkan kepuasan dari produk yang sama yang telah dikonsumsinya. (Dharmmesta dan Handoko, 2000). 
Keterbaruan dalam penelitian ini adalah kepuasan sebagai variabel mediasi sehingga persepsi harga, promosi penjualan dan citra merek dalam mempengaruhi berpengaruh terhadap loyalitas pelanggan. Persepsi harga, promosi penjualan dan citra merek diasumsikan memiliki pengaruh positif dan signifikan terhadap kepuasan pelanggan dan kepuasan memediasi citra merek, kualitas produk dan persepsi harga terhadap loyalitas pelanggan. Untuk membuktikan asumsi tersebut, diperlukan penelitian lebih jauh dengan melibatkan variabel tersebut. Penelitian tentang klinik kecantikan Larissa Aesthetic Center ini akan membahas mengenai hubungan variabel persepsi harga, promosi penjualan dan citra merek terhadap kepuasan dan pengaruh kepuasan pelanggan terhadap persepsi harga, promosi penjualan dan citra merek terhadap loyalitas pelanggan.

Penelitian oleh Yoganthara (2013), menemukan bahwa persepsi harga memiliki pengaruh positif terhadap kepuasan pelanggan. Penelitian oleh Montung dkk. (2015), menemukah bahwa persepsi harga mempunyari pengaruh yang signifikan positif secara parsial terhadap kepuasan pelanggan. Persepsi harga di Restoran Kawan Baru Manado telah dilaksanakan dengan baik, sehingga harga dipersepsikan positif oleh para pelanggan restoran. Penelitian oleh Liman (2016), menemukan bahwa persepsi harga berpengaruh positif terhadap kepuasan pelanggan.Berdasarkan hasil penelitian empiris diatas, maka hipotesis yang dapat disimpulkan adalah

$\mathrm{H}_{1}$ : Persepsi harga berpengaruh positif dan signifikan terhadap kepuasan pelanggan.

Saradissa (2015), meneliti dan menemukan bahwa berpengaruh signifikan terhadap kepuasan pelanggan Ijen Cafe N Resto disurabaya. Hasil penelitian 
Faradina (2016), menemukan bahwa promosi potif signifikan terhadap kepuasan pelanggan pada Rumah Cantik Alamanda. Pelanggan yang tidak mengetahui mengetahui sebuah produk karena tidak melakukan promosi maka konsumen cenderung akan melupakan adanya produk yang dipasarkan bahkan sehingga merugikan perusahaan.Berdasarkan hasil penelitian empiris diatas, maka hipotesis yang dapat disimpulkan adalah

$\mathrm{H}_{2}$ : Promosi penjualan berpengaruh positif dan signifikan terhadap kepuasan pelanggan.

Penelitian oleh Saputra (2013), menemukan bahwa citra merek yang baik akan meningkatkan kepuasan pelanggan. Harianto dan Subagio (2013), menemukan bahwa citra merek berpengaruh positif siginifikan terhadap kepuasan pelanggan. Penelitian oleh Pusparani dan Rastini (2014), menemukan bahwa kepuasan pelanggan dibentuk oleh merek, semakin baik citra merek dibenak konsumen makan konsumen akan merasa puas dalam menggunakan produk tersebut.Berdasarkan hasil penelitian empiris diatas, maka hipotesis yang dapat disimpulkan adalah

$\mathrm{H}_{3}$ : Citra merek berpengaruh positif dan signifikan terhadap kepuasan pelanggan

Penelitian oleh Rachmawati (2014), menemukan bahwa kepuasan pelanggan merupakan konsep inti dari loyalitas pelanggan, dimana tanpa kepuasan tidak akan terdapat loyalitas. Hasil serupa ditemukan pada penelitian yang dilakukan oleh Margaretha dan Sunaryo (2014), kepuasan pelanggan mempunyai pengaruh yang signifikan terhadap loyalitas pelanggan. Peningkatan kepuasan pelanggan 
akan meningkatkan loyalitas pelanggan terhadap suatu produk.Berdasarkan hasil penelitian empiris diatas, maka hipotesis yang dapat disimpulkan adalah

$\mathrm{H}_{4}$ : Kepuasan pelanggan berpengaruh positif dan signifikan terhadap loyalitas pelanggan.

Penelitian oleh Putri (2018) menyatakan bahwa kepuasan memediasi persepsi harga terhadap loyalitas pelanggan Angkringan Modern Playground Solo. Penelitian oleh Afifah (2014) yang menyatakan bahwa kepuasan berpengaruh dalam memediasi antara promosi dengan loyalitas pelanggan. Penelitian oleh Rivai dan Wahyudi (2017) menyatakan bahwa kepuasan memediasi citra merek terhadap loyalitas pelanggan. Hasil yang berbeda ditemukan oleh Penelitian Wijaya dan Nurcaya (2017) yang menyatakan bahwa kepuasan pelanggan berpengaruh tidak langsung dan tidak mampu sebagai mediator pengaruh kualitas produk dan harga terhadap loyalitas.Berdasarkan hasil penelitian empiris diatas, maka hipotesis yang dapat disimpulkan adalah

$\mathrm{H}_{5}$ : Kepuasan pelanggan mampu memediasi secara signifikan persepsi harga, promosi penjualan, dan citra merek terhadap loyalitas pelanggan.

\section{METODE PENELITIAN}

Penelitian ini dikategorikan sebagai penelitian kuantitatif kausalitas. Hal ini digambarkan dengan desain penelitian yang berusaha untuk meneliti dan menjelaskan hubungan sebab akibat yang melibatkan variabel persepsi harga, promosi penjualan dan citra merek terhadap kepuasan konsumen untuk meningkatkan loyalitas pada konsumen Larissa Aesthetic Center Denpasar.

Penelitian ini dilakukan di Kota Denpasar. Kota ini dipilih dikarenakan Kota Denpasar adalah ibukota Provinsi Bali. Kota Denpasar merupakan pusat 
pendidikan, perdagangan, kesehatan, dan tujuan urbanisasi masyarakat dari kabupaten lain sehingga secara tidak langsung penelitian ini dapat mewakili seluruh masyarakat yang ada di Provinsi Bali.

Objek yang digunakan dalam penelitian ini adalah perilaku konsumen, khususnya perilaku pelanggan klinik kecantikan Larissa Aesthetic Center. Loyalitas pelanggan dalam melakukan perawatan pada klinik kecantikan ditentukan oleh variabel persepsi harga, promosi penjualan, citra merek, dan kepuasan pelanggan di Larissa Aesthetic Center.

Variabel bebas dalam penelitian ini adalah persepsi harga $\left(\mathrm{X}_{1}\right)$, promosi penjualan $\left(\mathrm{X}_{2}\right)$ dan citra merek $\left(\mathrm{X}_{3}\right)$.Persepsi harga adalah bagaimana informasi harga yang ditawarkan dipahami seluruhnya oleh konsumen Larissa Aesthetic Center. Promosi adalah aktivitas yang mengkomunikasikan keunggulan produk dan membujuk pelanggan sasaran untuk membeli produk dan jasa Larissa Aesthetic Center.Citra merek merupakan proses dimana konsumen memilih, mengorganisasikan, dan mengartikan masukan informasi untuk menciptakan suatu gambaran yang berarti mengenai klinik kecantikan Larissa Aesthetic Center.

Variabel intervening dalam penelitian ini adalah kepuasan pelanggan yang disimbolkan dengan M.Kepuasan adalah perasaan senang atau kecewa seseorang yang muncul saat menggunakan produk dan jasa klinik kecantikan Larissa Aesthetic Center.

Variabel terikat pada penelitian ini yaitu loyalitas pelanggan yang disimbolkan dengan Y.Loyalitas adalah komitmen yang dipegang secara mendalam untuk membeli kembali produk atau jasa Larissa Aesthetic Center. 
Populasi dalam penelitian ini adalah konsumen atau member dari Larissa Aesthetic Center di Kota Denpasar.Ukuran sampel terbaik yang disarankan untuk mengukur multivariate adalah 5 sampai 10 dari jumlah indikator yang diteliti (Malhotra, 2006 : 291). Indikator yang digunakan dalam penelitian ini berjumlah 15 buah sehingga jika menggunakan formula maka ukuran sampel berada pada rentang $75-150$. Mengingat keterbatasan sumber daya maka dalam penelitian ini digunakan ukuran sampel 7 kali dari jumlah indikator, sehingga jumlah sampel yang digunakan adalah 105 sampel.Mengingat ukuran populasi tidak dapat diketahui dengan pasti, maka penentuan sampel dari penelitian ini menggunakan nonprobality sampling dengan metode purposive sampling, artinya pengambilan sampel yang dipilih berdasarkan pertimbangan tertentu dengan tujuan untuk memperoleh satuan sampel yang memiliki karakteristik yang dikehendaki (Sugiyono, $2016: 95)$.

Data yang digunakan terdiri atas data kualitatif dan data kuantitatif. Data kualitatif berupa pendapat dari responden mengenai pernyataan yang tertera dalam kuesioner, sedangkan data kuantitatif berupa usia dari responden yang mengisi kuesioner. Sebagian besar data bersumber dari sumber primer yaitu responden yang menjadi anggota sampel. Data yang dikumpulkan dari sumber primer antara lain tanggapan responden dari konsumen Larissa Aesthetic Center dalam kuesioner. Sementara itu, data dari sumber sekunder berupa data yang publikasi oleh pihak Larissa Aesthetic Center, publikasi tingkat popularitas Larissa Aesthetic CenterIndonesia oleh Top Brand Award, dan artikel dari situs berita online.

Analisis jalur merupakan teknik model analisis yang digunakan untuk menganalisis pola hubungan antar variabel dengan tujuan untuk mengetahui 
pengaruh langsung maupun tidak langsung seperangkat variabel bebas terhadap variabel terikat (Riduwan dan Kuncoro, 2008:2).

Persamaan struktural 1

$$
M=\beta_{1} X_{1}+\beta_{2} X_{2}+\beta_{3} X_{3}+\varepsilon_{1}
$$

Persamaan struktural 2

$$
\mathrm{Y}=\beta_{4} \mathrm{M}+\varepsilon_{2}
$$

Keterangan:

$\begin{array}{llll}\mathrm{Y} & =\text { Loyalitas pelanggan } & \mathrm{M} & =\text { Kepuasan pelanggan } \\ \mathrm{X}_{1} & =\text { Persepsi Harga } & \beta & =\text { Koefisien garis regresi } \\ \mathrm{X}_{2} & =\text { Promosi Penjualan } & \varepsilon & =\text { error } \\ \mathrm{X}_{3} & =\text { Citra merek } & & \end{array}$

Setelah menghitung koefisien regresi, selanjutnya dapat dihitung nilai error 1 dan error 2 dengan mengunakan rumus sebagai berikut,

$$
\varepsilon=\sqrt{1-R^{2}}
$$

Keterangan :

$$
\varepsilon \quad=\text { Error }
$$

$\boldsymbol{K}^{2}=$ Koefisien determinasi

Setelah nilai dari error 1 dan error 2 diketahui, maka selanjutnya dapat dihitung nilai dari koefisien determinasi total dengan rumus sebagai berikut:

$$
\mathrm{R}^{2} \mathrm{~m}=1-\left(\mathrm{P} \varepsilon_{1}\right)^{2}\left(\mathrm{P} \varepsilon_{2}\right)^{2}
$$

Keterangan :

$\mathrm{R}^{2} \mathrm{~m}=$ Koefisien determinasi total

$\mathrm{P} \varepsilon_{1} \quad=$ Nilai koefisien error 1

$\mathrm{P} \varepsilon_{2} \quad=$ Nilai koefisien error 2 


\section{HASIL DAN PEMBAHASAN}

Tabel 3.

Hasil Analisis Jalur Persamaan Regresi 1

\begin{tabular}{|c|c|c|c|c|c|}
\hline \multirow[t]{2}{*}{ Model } & \multicolumn{2}{|c|}{$\begin{array}{c}\text { Unstandardized } \\
\text { Coefficients }\end{array}$} & \multirow{2}{*}{$\begin{array}{c}\text { Standardized } \\
\text { Coefficients } \\
\text { Beta } \\
\end{array}$} & \multirow[t]{2}{*}{$\mathbf{T}$} & \multirow[t]{2}{*}{ Sig. } \\
\hline & B & Std. Error & & & \\
\hline (Constannt) & 2,102 & 0,893 & & 2,353 & 0,021 \\
\hline Persepsi Harga & 0,247 & 0,078 & 0,254 & 3,180 & 0,002 \\
\hline Promosi Penjualan & 0,244 & 0,95 & 0,242 & 2,319 & 0,013 \\
\hline Citra Merek & 0,523 & 0,83 & 0,547 & 6,286 & 0,000 \\
\hline
\end{tabular}

$\mathrm{R}_{1}{ }^{2}: 0,618$

F Statistik : 54,522

Sig F : 0,000

Sumber : data primer diolah, 2018.

$$
\mathrm{M}=0,254 \mathrm{X}_{1}+0,242 \mathrm{X}_{2}+0,547 \mathrm{X}_{3}+\mathrm{e}_{1}
$$

Tabel 4.

Hasil Analisis Jalur Persamaan Regresi 2

\begin{tabular}{|c|c|c|c|c|c|}
\hline \multirow[t]{2}{*}{ Model } & \multicolumn{2}{|c|}{$\begin{array}{c}\text { Unstandardized } \\
\text { Coefficient }\end{array}$} & \multirow{2}{*}{$\begin{array}{c}\begin{array}{c}\text { Standardized } \\
\text { Coefficient }\end{array} \\
\text { Beta } \\
\end{array}$} & \multirow[t]{2}{*}{$\mathbf{t}$} & \multirow[t]{2}{*}{ Sig. } \\
\hline & B & Std. Error & & & \\
\hline (Constant) & 2,254 & 1,022 & & 2,205 & 0,000 \\
\hline Kepuasan & 0,843 & 0,077 & 0,735 & 10,993 & 0,000 \\
\hline $\mathrm{R} 2^{2}$ & 0,540 & & & & \\
\hline F Statistik & : 120,839 & & & & \\
\hline Sig F & $: 0,000$ & & & & \\
\hline
\end{tabular}

Berdasarkan data yang disajikan pada Tabel 4, maka persamaan structural untuk hipotesis 4 dapat disusun sebagai berikut :

$$
\mathrm{Y}=0,735 \mathrm{M}+\mathrm{e}_{2}
$$

\begin{tabular}{|c|c|c|}
\hline $\begin{array}{l}\mathrm{Y}=\text { Loyalitas pelanggan } \\
\mathrm{X}_{1}=\text { Kualitas produk }\end{array}$ & M & $\begin{array}{l}=\text { Kepuasan pelanggan } \\
=\text { Koefisien garis regresi }\end{array}$ \\
\hline $\mathrm{X}_{2}=$ Persepsi harga & $e_{1}$ & $=$ error 1 \\
\hline$X_{3}=$ Citra merek & $e_{2}$ & $=$ error 2 \\
\hline
\end{tabular}

Keterangan : 
Berdasarkan persamaan regresi 1 dan persamaan regresi 2, diketahui nilai $\mathrm{R}_{1}{ }^{2}=0,618$ dan $\mathrm{R}_{2}^{2}=0,540$, maka nilai eror untuk masing-masing persamaan adalah sebagai berikut:

$\mathrm{e}=\sqrt{1-\mathrm{Ri}^{2}}$

$\mathrm{e}_{1}=\sqrt{1-\mathrm{R}_{1}{ }^{2}}=\sqrt{1-0,618^{2}}=0,786$

$\mathrm{e}_{2}=\sqrt{1-\mathrm{R}_{2}{ }^{2}}=\sqrt{1-0,540^{2}}=0,842$

Berdasarkan perhitungan nilai standar eror, didapatkan hasil $\mathrm{e}_{1}$ sebesar 0,786 dan $\mathrm{e}_{2}$ sebesar 0,842 . Hasil koefisien determinasi total dapat dihitung sebagai berikut:

$\mathrm{R}^{2} \mathrm{~m}=1-\left(\mathrm{Pe}_{1}\right)^{2}\left(\mathrm{Pe}_{2}\right)^{2}$

$=1-(0,786)^{2}(0,842)^{2}=0,562$

Koefisien determinasi total sebesar 0,562 , artinya sebesar $56,2 \%$ variasi variabel loyalitas pelanggan dijelaskan oleh variabel kepuasan pelanggan, persepsi harga, promosi penjualan, dan citra merek, sedangkan sisanya sebesar $43,8 \%$ dijelaskan oleh faktor lain yang tidak dimasukkan kedalam model.

Hasil pada Tabel 3 dan 4 menunjukkan nilai koefisien sig. $\mathrm{F}$ adalah 0,000. Nilai koefisien ini lebih kecil dari 0,05 sehingga dapat disimpulkan bahwa model persamaan struktural 1 dan 2 telah memenuhi syarat Goodness of Fit melalui uji F.

Dari nilai beta pada masing - masing persamaan regresi yang telah disajikan pada Tabel 3 dan 4. Maka koefisien signifikasi path pada masing - masing hipotesis dapat dijabarkan sebagai berikut,

Hasil pada Tabel 3 diketahui pengaruh kualitas produk terhadap kepuasan 
pelanggan memiliki koefisien ${ }_{1}=0,254$ dan value $=0,002$. Nilai koefisien ${ }_{1}>0$ dan value $\leq 0,05$ sehingga H1diterima dan $\mathrm{H} 0$ ditolak. Itu berarti persepsi harga berpengaruh positif dan signifikan terhadap kepuasan pelanggan.

Hasil pada Tabel 3 diketahui pengaruh promosi penjualan terhadap kepuasan pelanggan memiliki koefisien $2_{2}=0,242$ dan value $=0,013$. Nilai koefisien $_{2}>0$ dan value $\leq 0,05$ sehingga H2diterima dan H0 ditolak. Itu berarti promosi penjualan berpengaruh positif dan signifikan terhadap kepuasan pelanggan.

Hasil pada Tabel 3 diketahui pengaruh citra merek terhadap kepuasan pelanggan memiliki nilai koefisien ${ }_{3}=0,547$ dan value $=0,000$. Nilai koefisien ${ }_{3}>$ 0 dan value $\leq 0,05$ sehingga $\mathrm{H} 3$ diterima dan $\mathrm{H} 0$ ditolak. Itu berarti citra merek berpengaruh positif dan signifikan terhadap kepuasan pelanggan.

Hasil pada Tabel 4 diketahui pengaruh kepuasan pelanggan terhadap loyalitas pelanggan memiliki koefisien ${ }_{4}=0,735$ dan value $=0,000$. Nilai koefisien $_{4}>0$ dan value $\leq 0,05$ sehingga H4diterima dan $\mathrm{H} 0$ ditolak. Itu berarti kepuasan pelanggan berpengaruh positif dan signifikan terhadap loyalitas pelanggan.

Hasil dari perhitungan uji sobel menunjukan bahwa kepuasan pelanggan memediasi persepsi harga, promosi penjualan, dan citra merek terhadap loyalitas pelanggan. Hal tersebut dapat dilihat dari hasil t hitung semua variabel $>1,96$.

Tabel 5.

Nilai Koefisien $\beta$ dan $\rho$ Value Masing-masing Variabel

\begin{tabular}{clcc}
\hline No & \multicolumn{1}{c}{ Hubungan Antar Variabel } & Koefisien $\boldsymbol{\beta}$ & P value \\
\hline 1. & Persepsi harga $\rightarrow$ Kepuasan Pelanggan & 0,254 & 0,002 \\
2. & Promosi Penjualan $\rightarrow$ Kepuasan Pelanggan & 0,242 & 0,013 \\
3. & Citra Merek $\rightarrow$ Kepuasan Pelanggan & 0,547 & 0,000 \\
4. & Kepuasan $\rightarrow$ Loyalitas Pelanggan & 0,735 & 0,000 \\
\hline
\end{tabular}


Sumber : data primer diolah, 2018

Tabel 5 diketahui nilai dari seluruh koefisien $\beta>0$ dan nilai $\rho$ value $\leq 0,05$ sehingga $\mathrm{H}_{1}, \mathrm{H}_{2}, \mathrm{H}_{3}$ dan $\mathrm{H}_{4}$ diterima dan $\mathrm{H}_{0}$ ditolak. Persepsi Harga, Promosi Penjualan, dan Citra Merek berpengaruh positif dan signifikan terhadap Kepuasan Pelanggan. Hasil yang sama juga diperoleh dari variabel Kepuasan Pelanggan berpengaruh positif dan signifikan terhadap loyalitas Pelanggan. Nilai error pada masing masing persamaan yaitu $\varepsilon_{1}=0,786$ dan $\varepsilon_{2}=0,842$. Nilai determinasi total yaitu 0,562 yang artinya bahwa $56,2 \%$ variasi variabel loyalitas pelanggan dijelaskan oleh variabel kepuasan pelanggan, persepsi harga, promosi penjualan, dan citra merek sedangkan sisanya sebesar $43,8 \%$ dijelaskan oleh faktor yang tidak dimasukkan kedalam model.

Hasil uji pengaruh kepuasan pelangan memediasi persepsi harga terhadap loyalitas pelanggan.

$$
\begin{aligned}
& t=\frac{a b}{\sqrt{b^{2} s_{a}^{2}+a^{2} s_{b}^{2}+s_{a}^{2} s_{b}^{2}}} \\
& t=\frac{0,254 \times 0,735}{\sqrt{0,735^{2} \times 0,078^{2}+0,254^{2} \times 0,077^{2}+0,078^{2} \times 0,077^{2}}} \\
& t=\frac{0,18669}{\sqrt{0,540225 \times 0,006084+0,064516 \times 0,005929+0,006084 \times 0,005929}} \\
& t=\frac{0,18669}{\sqrt{0,00329+0,000382+0,0000360}} \\
& t=\underline{0,18669} \\
& \sqrt{0,003708} \quad=3,066 \\
& t=\underline{0,18669}
\end{aligned}
$$


Berdasarkan perhitungan diperoleh nilai t hitung sebesar 3,066. Nilai t hitung sebesar 3,066 lebih besar dari 1,96. Jika nilai kalkulasi t hitung lebih besar dari t tabel sebesar 1,96 maka variabel mediator kepuasan pelanggan termasuk ke dalam mediasi parsial karena dinilai secara signifikan memediasi hubungan antara persepsi harga terhadap loyalitas pelanggan.

Hasil uji pengaruh kepuasan pelangan memediasi promosi penjualan terhadap loyalitas pelanggan.

$$
\begin{aligned}
& t=\frac{a b}{\sqrt{b^{2} s_{a}^{2}+a^{2} s_{b}^{2}+s_{a}^{2} s_{b}^{2}}} \\
& t=\frac{0,242 \times 0,735}{\sqrt{0,735^{2} \times 0,095^{2}+0,242^{2} \times 0,077^{2}+0,095^{2} \times 0,077^{2}}} \\
& t=\frac{0,1778}{\sqrt{0,540225 \times 0,0009025+0058564 \times 0,005929+0,009025 \times 0,005929}} \\
& t=\frac{0,17787}{\sqrt{0,00487+0,000347+0,0000535}} \\
& t=\underline{0,17787} \quad \sqrt{0,00527} \quad=2,450 \\
& t=\frac{0,17787}{0,07259}
\end{aligned}
$$

Berdasarkan perhitungan diperoleh nilai t hitung sebesar 2,450. Nilai t hitung sebesar 2,450 lebih besar dari 1,96. Jika nilai kalkulasi t hitung lebih besar dari t tabel sebesar 1,96 maka variabel mediator kepuasan pelanggan termasuk ke dalam mediasi parsial karena dinilai secara signifikan memediasi hubungan antara promosi penjualan terhadap loyalitas pelanggan. 
Hasil uji pengaruh kepuasan pelangan memediasi citra merek terhadap loyalitas pelanggan.

$$
\begin{aligned}
& t=\frac{a b}{\sqrt{b^{2} s_{a}^{2}+a^{2} s_{b}^{2}+s_{a}^{2} s_{b}^{2}}} \\
& t=\frac{0,547 \times 0,735}{\sqrt{0,735^{2} \times 0,083^{2}+0,547^{2} \times 0,077^{2}+0,083^{2} \times 0,077^{2}}} \\
& t=\frac{0,402045}{\sqrt{0,54025 \times 0,006889+0,299209 \times 0,005929+0,006889 \times 0,005929}} \\
& t=\frac{0,402045}{\sqrt{0,00372+0,00177+0,0000408}} \\
& t=\underline{0,402045} \\
& \sqrt{0,005530} \\
& t=\frac{0,402045}{0,074369}=5,406
\end{aligned}
$$

Berdasarkan perhitungan diperoleh nilai t hitung sebesar 5,406. Nilai t hitung sebesar 5,406 lebih besar dari 1,96. Jika nilai kalkulasi t hitung lebih besar dari t tabel sebesar 1,96 maka variabel mediator kepuasan pelanggan termasuk ke dalam mediasi parsial karena dinilai secara signifikan memediasi hubungan antara citra merek terhadap loyalitas pelanggan..

Pengujian hipotesis terhadap hubungan antara variabel persepsi harga dan kepuasan pelanggan menunjukkan hasil yang diterima, yaitu persepsi harga berpengaruh positif dan signifikan terhadap kepuasan pelanggan. Itu berarti, semakin baik persepsi harga klinik kecantikan Larissa Aesthetic Center, maka akan semakin tinggi kepuasan pelanggan terhadap produk dan jasa yang didapatkan.Hasil rangkuman penilaian responden yang disajikan dalam deskripsivariabel penelitian menunjukkan bahwa penilaian responden terhadap 
persepsi harga berada dalam kategori sangat baik sehingga menghasilkan tingkat kepuasan berada dalam kategori sangat baik. Responden merasa puas dengan Attractiveness dan manfaat yang dirasakan yang dimiliki klinik kecantikan Larissa Aesthetic Center. Strategi Larissa Aesthetic Center dengan fokus menyasar konsumen segmen menengah menjadikan Larissa Aesthetic Center menawarkan harga yang terjangkau namun tetap menjaga kualitas produknya sehingga mampu meningkatkan kepuasan konsumen. Konsumen meras puas terhadap manfaat yang dirasakan dengan harga yang dibayarkan saat menggunakan produk dan jasa klinik kecantikan Larissa Aesthetic Center.

Pengujian hipotesis terhadap hubungan antara variabel promosi penjualan dan variabel kepuasan pelanggan menunjukkan hasil yang diterima, yaitu promosi penjualan berpengaruh positif dan signifikan terhadap kepuasan pelanggan. Itu berarti, semakin baik promosi penjualan yang dilakukan klinik kecantikan Larissa Aesthetic Center, maka semakin tinggi kepuasan pelanggan.Hasil rangkuman penilaian responden yang disajikan dalam deskripsi variabel penelitian menunjukkan bahwa penilaian responden terhadap promosi penjualan berada dalam kategori sangat baik sehingga menghasilkan tingkat kepuasan berada dalam kategori sangat baik. Responden merasa puas dengan kesesuaian promosi yang dilakukan klinik kecantikan Larissa Aesthetic Center. Strategi promosi penjualan yang dilakukan Larissa Aesthetic Centerdengan memanfaatkan media sosial agar menarik minat pembeli baru. Promosi tidak hanya dilakukan untuk menarik pembeli baru namun dilakukan bagi pelanggan setia klinik kecantikan Larissa Aesthetic Center berupa hadiah atau voucher sehingga mampu meningkatkan 
kepuasan pelanggan.

Pengujian hipotesis terhadap hubungan kedua variabel ini menunjukkan hasil yang diterima, yaitu citra merek berpengaruh positif dan signifikan terhadap kepuasan pelanggan. Itu berarti, semakin baik citra merek yang dimiliki klinik kecantikan Larissa Aesthetic Center, maka akan semakin tinggi kepuasan pelanggan.Hasil rangkuman penilaian responden yang disajikan dalam deskripsi variabel penelitian menunjukkan bahwa penilaian responden terhadap citra merek berada dalam kategori sangat baik sehingga menghasilkan tingkat kepuasan berada dalam kategori sangat baik. Responden merasa puas dengan manfaat fungsional yang dimiliki klinik kecantikan Larissa Aesthetic Center. StrategiLarissa Aesthetic Centerdalam menjaga kualitas dengan menggunakan bahan natural meskipunmenawarkan harga yang terjangkau mampu meningkatkan nilai dari citra mereknya. Larissa Aesthetic Center mampu membangun citra merek yang baik dibenak konsumen ditengah banyaknya pesaing- pesaing atau klinik kecantikan yang menawarkan produk dan jasa treatmen dengan hasil yang cepat (instant). Manfaat fungsionalyang tergambar pada citra merek Larissa Aesthetic Center mampu meningkatkan kepuasan pelanggan.

Pengujian hipotesis terhadap hubungan antara variabel kepuasan pelanggan dan loyalitas pelanggan menunjukkan hasil yang diterima, yaitu kepuasan pelanggan berpengaruh positif dan signifikan terhadap loyalitas pelanggan. Itu berarti, semakin baik kepuasan yang dirasakan pelanggan klinik kecantikan Larissa Aesthetic Center, maka akan semakin tinggi pula loyalitas pelanggan terhadap produk tersebut.Hasil rangkuman penilaian responden yang disajikan 
dalam deskripsi variabel penelitian menunjukkan bahwa kepuasan pelanggan berada dalam kategori sangat baik sehingga menghasilkan tingkat loyalitas pelanggan berada dalam kategori sangat baik. Responden menjadi pelanggan yang loyal karena merasa puas dengan klinik kecantikan Larissa Aesthetic Center. Persepsi harga, promosi penjualan, dan citra merek klinik kecantikan Larissa Aesthetic Center mampu meningkatkan kepuasan pelanggan. Kepuasan ini berdampak secara positif dan signifikan terhadap loyalitas pelanggan Larissa Aesthetic Center. Strategi Larissa Aesthetic Center dalam meningkatkan kepuasan pelanggannya dengan menghadirkan persepsi harga yang baik, promosi penjualan yang baik dan citra yang kuat mampu menciptakan loyalitas pelanggan. Pelanggan yang loyal ini akan merekomendasikan klinik kecantikan Larissa Aesthetic Center yang digunakannya kepada orang lain. Rekomendasi ini akan membantu perusahaan dalam mendatangkan konsumen baru.

Hasil pada analisis jalur pada Tabel 3 dapat diketahui variabel citra merek merupakan variabel yang paling berpengaruh terhadap kepuasan pelanggan. Citra Larissa Aesthetic Center sebagai klinik kecantikan yang berkompeten memiliki pengaruh paling besar dalam meningkatkan kepuasan pelanggan. Diposisi kedua, variabel persepsi harga merupakan variabel yang dapat mempengaruhi kepuasan pelanggan, harga yang menarik dan kesesuaian manfaat yang dirasakan dengan harga yang dibayarkan, berpengaruh terhadap kepuasan pelanggan. Diposisi terakhir, adalah variabel promosi penjualan yang berpengaruh terhadap kepuasan pelanggan. Ketetapan atau kesesuaian promosi dengan menggunakan media sosial sehinggan manarik minat pembeli baru dan memberi hadiah pada pelanggan setia 
mampu menciptakan kepuasan pelanggan. Ketiga variabel ini dapat menciptakan kepuasan pelanggan pada klinik kecantikan Larissa Aesthetic Center, dampak lebih jauhnya kepuasan ini telah menciptakan loyalitas pelanggan. Pelanggan yang loyal, akan merekomendasikan klinik kecantikan Larissa Aesthetic Center kepada orang lain.

Pengujian hipotesis terhadap hubungan pengaruh persepsi harga, promosi penjualan terhadap kepuasan untuk meningkatkan loyalitas pelanggan menunjukan hasil yang diterima, yaitu kepuasan mampu memediasi citra merek, kualitas produk dan persepsi harga terhadap niat beli ulang. Berdasarkan perhitungan dari pengaruh kepuasan memediasi persepsi harga terhadap loyalitas pelanggan diperoleh nilai t hitung sebesar 3,066 menunjukkan bahwa nilai $\mathrm{t}$ hitung lebih besar dari 1,96. Jika nilai kalkulasi t hitung lebih besar dari t tabel sebesar 1,96 maka variabel mediator kepuasan pelanggan termasuk ke dalam mediasi parsial karena dinilai secara signifikan memediasi hubungan antara persepsi harga terhadap loyalitas pelanggan. Perhitungan mengenai kepuasan memediasi promosi penjualan terhadap loyalitas pelanggan memperoleh hasil nilai thitung sebesar 2,450. Nilai t hitung sebesar 2,450 lebih besar dari 1,96. Jika nilai kalkulasi t hitung lebih besar dari t tabel sebesar 1,96 maka variabel mediator kepuasan pelanggan termasuk ke dalam mediasi parsial karena dinilai secara signifikan memediasi hubungan antara promosi penjualan terhadap loyalitas pelanggan, dan berdasarkan dilihat secara signifikan memediasi hubungan antara citra merek terhadap loyalitas pelanggan. Berdasarkan perhitungan diperoleh nilai t hitung sebesar 5,406. Nilai t hitung sebesar 5,405 lebih besar dari 1,96. Jika nilai 
kalkulasi t hitung lebih besar dari t tabel sebesar 1,96 maka variabel mediator kepuasan pelanggan termasuk ke dalam mediasi parsial karena dinilai secara signifikan memediasi hubungan antara citra merek terhadap loyalitas pelanggan.

\section{SIMPULAN DAN SARAN}

Berdasarkan hasil penelitian, dapat ditarik simpulan bahwa Persepsi harga berpengaruh positif dan signifikan terhadap kepuasan pelanggan. Promosi penjualan berpengaruh positif dan signifikan terhadap kepuasan pelanggan. Citra merek berpengaruh positif dan signifikan terhaap kepuasan pelanggan. Kepuasan pelanggan berpengaruh positif dan signifikan terhadap loyalitas pelanggan. Kepuasan pelanggan mampu memediasi secara signifikan persepsi harga, promosi penjualan, dan citra merek terhadap loyalitas pelanggan. Hasil ini dibuktikan dengan menggunakan uji sobel dan dilihat dari hasil t hitung semua variabel > 1,96 .

Berdasarkan kesimpulan yang telah dipaparkan, beberapa saran yang dapat diberikan baik kepada perusahaan dan penelitian selanjutnya adalah harus tetap menjaga kualitas produk sehingga menimbulkan kepuasan bagi konsumen. Promosi penjualan yang dilakukan perusahaan harus sesuai dan tepat sehingga mampu mempertahan pelanggan dan menarik minta pembeli baru. Harus mempunyai keunikan dibandingkan dengan perusahaan lain sehingga memiliki cita merek dibenak konsumen. Perusahaan harus mampu memenuhi harapan konsumen dengan memberikan pelayanan dan produk yang berkualitas. Oleh karena itu perusahaan harus mampu memberikan kualitas terbaik bagi konsumen sehingga menimbulkan niat menggunakan dan membeli kembali produk 
perusahaan tersebut. Konsumen yang kecewa akan produk atau jasa sangat berpengaruh bagi perkembangan perusahaan.

\section{REFERENSI}

Amryyanti, R, Sukaatmadja, I.P.G, dan Cahya, K. N. (2013). Pengaruh Kualitas Layanan, Produk dan Kewajaran Harga Terhadap Kepuasan dan Loyalitas Pelanggan Pada LnC Skin Care Singaraja. Jurnal Ekonomi dan Bisnis, 02(01). 22-29.

Briliana, Vita. (2013). Pengaruh Kepuasan, Komitmen, Manfaat Sosial, Dan Spesial Treatment Benefits Terhadap Loyalitas Pelanggan. Jurnal Bisnis dan Akuntansi 1, 15(1).

Chaeriah, Ella Siti. (2016). Pengaruh Harga, Citra Merek, Dan Kualitas Produk Terhadap Loyalitas Pengguna Smartphone Samsung (Studi Pada Mahasiswa Magister Manajemen UNKRIS). Jurnal Manajemen Bisnis Krisnadwipayana, 4(3), hal.1-9.

Darmawan, Putu Ayu Dessy Trisnadewi, dan Ni Wayan Ekawati. (2017). Pengaruh Kepuasan Konsumen Memediasi Harga Terhadap Loyalitas Konsumen Dalam Berbelanja Pada Florist Online Di Kota Denpasar. EJurnal Manajemen Universitas Udayana, 6(4), hal.2076-2104.

Dharmmesta, Drs. Basu Swastha dan Handoko, Drs. T. Hani. (2000). Manajemen Pemasaran: Analisa Perilaku Konsumen, Edisi Pertama. Yogyakarta: BPFE.

Faradina, Anissa. (2016). Pengaruh Promosi dan Kualitas Pelanggan Terhadap Kepuasan Pelanggan Rumah Cantik Alamanda. Jurnal Ilmu dan Riset Manajemen, 5(7), hal. 1-18.

Ghozali, Imam. (2016). Aplikasi Analisis Multivariete dengan Program IBM SPSS 21. Semarang. Badan Penerbit Universitas Diponegoro.

Harianto, David dan Hartono Subagio. (2013). Analisia Pengaruh Kualitas Layanan, Brand Image Dan Atmosfer Terhadap Loyalitas Dengan Kepuasan Konsumen Sebagai Variabel Intervening Konsumen Kedai Deja-Vu Surabaya. Jurnal Manajemen Pemasaran, 1(1), hal.1-8.

Hermawan, Budi. (2011). Pengaruh Kualitas Produk Terhadap Kepuasan, Reputasi Merek, Dan Loyalitas Konsumen Jamu Tolak Angin PT. SIDO MUNCUL. Jurnal Manajemen Teori dan Terapan, 2(1), hal. 09-17.

Khan, Shahzad; Hussain, Syed Majid; Yaqoob, Fahad, (2012). Determinants of Customer Satisfaction in Fast Food Industry. International Journal of Management and Strategy, 3(5), hal. 1-15 
Kotler, Philip and Kevin Lane Keller.(2009). Manajemen Pemasaran Edisi Ketiga Belas Jilid 1. Jakarta : Erlangga.

Kotler, Philip dan Gary Armstrong. (2008). Prinsip-Prinsip Pemasaran Edisi Kedua Belas Jilid 1. Jakarta: Erlangga.

Liman, Piter. (2016). Analisis Pengaruh Kualitas Produk, Kualitas Layanan dan Persepsi Harga Terhadap Kepuasan Pelanggan Pada Minyak Goreng Kemasan CV.Indo Sari Abadi. Jurnal Komunikasi Bisnis dan Manajemen, 3(6), hal.95-107

Malhotra, Naresh K. (2006). Riset Pemasaran: Pendekatan Terapan Jilid 1. Jakarta :Indeks.

Margaretha, Dona dan Sunaryo. (2014). Pengaruh Kualitas Produk dan Saluran Distribusi Terhadap Loyalitas Merek Melalui Kepuasan Pelaggan (Studi Kasus Konsumen Penikmat Rokok Tambang Emas Alami Dan Coklat Alami). Jurnal Ilmiah Mahasiswa FEB Universitas Brawijaya, 3(2), hal. 54- 69.

Montung, Pamela, Jantje Sepang dan Decky Adare. (2015). Pengaruh Kualitas Produk, Kualitas Layanan dan Persepsi Harga Terhadap Kepuasan Pelanggan Di Restoran Kawan Baru. Jurnal Berkala Ilmiah Efisiensi, 15(5), hal.678 - 689 .

Peter, J. Paul and Jerry C. Olson. (2000). Consumer Behavior : Perilaku Konsumendan Strategi Pemasaran Jilid 1 Edisi Keempat. Jakarta : Erlangga.

Purbarani, Vidya Hanesty. (2013). Analisis Pengaruh Persepsi Harga, Kualitas Produk, Diferensiasi Produk, Citra Merek Dan Promosi Terhadap Kepuasan Pelanggan (Studi pada Konsumen Larissa Aesthetic Center Semarang). Jurnal Manejemen Universitas Diponegoro, 2(10), hal. 1-14.

Pusparani, Putu Ayu Yulia dan Ni Made Rastini. (2014). Pengaruh Kualitas Produk Dan Brand Image Terhadap Kepuasan Konsumen dan Loyalitas Pelanggan Kamera Canon Digital Single Lens Reflex (DSLR) Di Kota Denpasar. E-Jurnal Manajemen Universitas Udayana, 3(5), hal.1311-1319.

Putri, Desa Irana, Wahyu Hidayat dan Reni Shinta Dewi. (2013). Pengaruh Kualitas Produk Dan Lokasi Terhadap Loyalitas Pelanggan Memalui Kepuasan Pelanggan Sebagai Variabel Intervening. Jurnal Administrasi Bisnis, 2(2), hal.1-9.

Rachmawati, Rina. (2014). Pengaruh Kepuasan Terhadap Loyalitas Pelanggan (Sebuah Kajian Terhadap Bisnis Makanan). Teknobuga, 1(1), hal.66 - 79.

Riduwan dan Kuncoro, Engkos Achmad. (2008). Cara Menggunakan dan Memakai Analisis Jalur (Path Analysis). Bandung : Alfabeta. 
Saputra, Falla Ilhami. (2013). Kualitas Layanan, Citra Dan Pengaruhnya Terhadap Loyalitas Melalui Kepuasan Pelanggan (Studi Pada PT. Bank BNI 46 Sentra Kredit Kecil Surabaya).Jurnal Aplikasi Manajemen Universitas Brawijaya, 11(3), hal.445 - 457.

Saradissa, C. N. (2015). Pengaruh Harga, Promosi, Kualitas Pelayanan, Dan Lokasi Terhadap Kepuasan Pelanggan. Jurnal Ilmu dan Riset Manajemen. 4(11), hal. 7-11.

Selmi Dedy. (2007). Pengaruh Kualitas Layanan terhadap Nilai Pelanggan, Kepuasan Pelanggan dan Perilaku Pasca Pembelian (Studi pada Pelanggan PT Matahari Putra Prima, Tbk di Jawa Timur). Jurnal Aplikasi Manajemen. 5(3) hal. 403-411.

Sengkey, Lenny dan Willem Tumbuan. (2014). Strategi Relationship Marketing Dan Promosi Pengaruhnya Terhadap Kepuasan Konsumen Di Rumah Sakit Ibu Dan Anak "Kasih Ibu” Manado. Jurnal EMBA. 2(1), hal. 182191.

Seno, Diana dan Lukas Bryan A. (2007). The Equity of Product Endorsement by Celebrities a Conceptual Framework From a Co Branding Perspective. European Journal of Marketing, 41(1/2). pp. 121-134.

Sinaga, Krisman dan Rini Novianti. (2016). Analisis Pengaruh Citra Merek, Kualitas Produk dan Persepsi Harga Terhadap Loyalitas Konsumen Produk Pasta Gigi Pepsodent. Global, 1(10), hal. 1 - 11.

Sugiyono. (2016). Metode Penelitian Administratif Dilengkapi Dengan MetodeR\&D. Bandung : Alfabeta.

Sulastri, Tuti. (2017). Pengaruh Kualitas Pelayanan dan Persepsi Harga Terhadap Kepuasan Mahasiswa Serta Implikasinya Pada Citra Perguruan Tinggi. Jurnal Inspirasi Bisnis dan Manajemen, 1(1), hal.41-52.

Susanti, Ni Putu Hani dan I Made Wardana. (2015). Pengaruh Kualitas Produk dan Citra Merek Terhadap Kepuasan dan Loyalitas Pelanggan Pada Produk Kosmetik Hijau Merek The Body Shop. E-Jurnal Manejemen UniversitasUdayana, 4(5), hal.622-636.

Tjiptono, Fandy. (2005). Pemasaran Jasa. Malang: Bayumedia Publishing.

Tjiptono, Fandy. (2008). Strategi Pemasaran Edisi 3.Yogyakarta :ANDI.

Yoganthara, Agasi Aji. Pengaruh Persepsi Harga Dan Kualitas Pelayanan Terhadap Loyalitas Melalui Kepuasan Konsumen (Studi Empiris Pada Radja Futsal Stadius Cabang Majapahit Semarang). Jurnal Dimanika Manajemen, 2(5), hal.113-128. 